\title{
Migration, Corruption, and Ideological Centrism: Explana- tions of Anti-Establishment Attitudes in the Czech Republic ${ }^{1}$
}

\author{
Ondrej Škvarenina - Vlastimil Havlík - Veronika Dostálová ${ }^{2}$ \\ Department of Political Science, Faculty of Social Studies, Masaryk Univer- \\ sity, Brno
}

\begin{abstract}
Migration, Corruption, and Ideological Centrism: Explanations of Anti-Establishment Attitudes in the Czech Republic. Although the Czech Republic has experienced an unprecedented rise of anti-establishment political parties in recent decades, a systematic examination of anti-establishment attitudes among the public is still missing from the scholarly literature. This paper tests different explanations for anti-establishment attitudes among the voting population, working with the concepts of anti-political establishment parties, populism, and taking into account the specific national context. Using original data from the 2017 Czech National Election Study $(N=919)$, we show that anti-establishment attitudes among the Czech public stem from feelings of low political efficacy, the perceived salience of corruption, and anti-immigration attitudes. These results demonstrate that researchers need to consider contextual specifics, including the nature of diverse antiestablishment actors, when searching for the causes of anti-establishment attitudes in a particular country or region.

Sociológia 2021, Vol. 53 (No. 3: 287-308)

https://doi.org/10.31577/sociologia.2021.53.3.11
\end{abstract}

Key words: Anti-establishment politics; attitudes; public opinion; Czech Republic; populism

Introduction

In Europe, being a politician rarely means having a job which earns you fondness from the public. In a comparative study carried out across nine European countries, the majority of respondents in each country agreed with the statement that "politicians always end up agreeing when it comes to protecting their privileges" (Anduiza - Rico 2016). The lack of sympathy for politicians is also indirectly reflected in a remarkably low level of trust in political institutions. Not once since 2007 has the average level of trust in either the national government or the national parliament exceeded $50 \%$ in any of the 27 EU countries (European Commission 2018). This lack of confidence has translated into decreasing voter turnout (Mair 2013) and increasing electoral support all across Europe for parties employing anti-establishment or antipolitical rhetoric (see e.g. Abedi 2002; Schedler 1996). Their share of national

1 Vlastimil Havlik worked on this article in the framework of the grant project Radicalization of Politics in Central Europe in Times of Crises (GA17-09296S) sponsored by the Grant Agency of the Czech Republic. Ondrej Škvarenina a Veronika Dostálová worked on this article at Masaryk University with the support of the Specific University Research Grant provided by the Ministry of Education, Youth and Sports of the Czech Republic (Aktuální problémy politologického výzkumu VII. (MUNI/A/1324/2020).

2 Address: Bc. Ondrej Škvarenina, doc. Vlastimil Havlík, Ph.D., Mgr. Veronika Dostálová, Department of Political Science, Faculty of Social Studies, Masaryk University, Joštova 10, 60200 Brno, Czech Republic. E-mail: o.skvarenina@gmail.com; havlik@fss.muni.cz; 414804@mail.muni.cz

Sociológia 53, 2021, No. 3 
parliamentary seats almost tripled between 1960 and 2014 (Inglehart - Norris 2016).

The Czech Republic has not been an exception to this trend. On the contrary, suspicion of politicians seems to be deeply rooted in the mentality of Czech citizens, with its origins in the tradition of anti-political thinking (Havelka 1998). Following corruption scandals and consequent decrease in political trust (Havlík 2015), the last three general elections have been characterized by the great success of a variety of anti-political establishment parties, including the social-liberal left-wing Pirates, centrist ANO and Public Affairs, as well as the far-right Dawn of Direct Democracy that eventually became the Freedom and Direct Democracy Party, and to some extent also the left-wing Communist Party of Bohemia and Moravia. Despite significant differences in their discourse, all these parties have been critical of the established mainstream political parties or have presented themselves as an alternative to such parties. In the 2017 Czech legislative election, anti-political establishment parties even secured the majority of votes, turning the Czech Republic into a "laboratory" for anti-establishment party politics.

Despite the unprecedented rise of political parties building their success by taking an anti-establishment stand, only little is known about causes of the manifestations of anti-establishment politics among the public - people's antiestablishment attitudes. Using original data from the 2017 Czech National Election Study, ours is the first study to investigate the correlations of antiestablishment attitudes among the Czech electorate. In doing so, we aim to deepen the understanding of contemporary Czech society and politics. By focusing on the as yet unexplored Czech context, unique for the exceptional electoral success of different types of anti-establishment political parties, including those with a centrist ideological profile, this study also represents a significant contribution to the existing research on anti-establishment attitudes in Central and Eastern Europe and elsewhere.

Anti-establishment attitudes

One of the major challenges in explaining anti-establishment attitudes certainly lies in the lack of clarity in defining the concept itself. As a starting point for conceptualization of anti-establishment attitudes, we therefore briefly review the existing literature on anti-political establishment parties (AEPs) and the closely related concept of populism.

To capture the core characteristics of anti-political establishment parties, Schedler (1996) defines a triangular space for the relationships between three actors: the political class, the people, and the AEPs (Figure 1). The positioning of the actors is crucial for understanding of the nature of AEPs. While the relationship between both the people and AEPs towards the political class is 
highly antagonistic - with political elites described with emotional language as traitors of the people, corrupt, selfish, or incompetent, AEPs align with the people by presenting themselves as the only pure advocate of the interests of the people (Schedler 1996). Consequently, according to AEPs, the most fundamental cleavage in society is "the conflict between the 'ruled' and 'rulers' (...), audience and politics, voters and parties, citizens and politicians, society and state, electorate and elected, (silent) majority and elite" (Schedler 1996: 294; see also Abedi 2002; Hanley - Sikk 2016).

\section{Figure 1: Anti-political triangle}

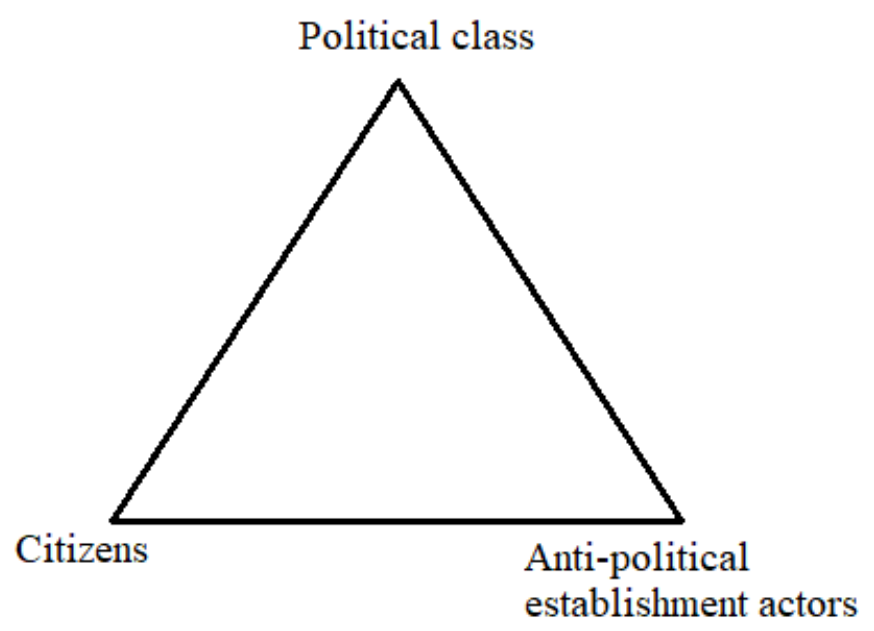

Source: The authors based on Schedler (1996: 294)

Similarly to Schedler, and following Sartori's concept of establishment parties and the notion of the governing potential and governmental relevance, Abedi (2002) formulated three definitional criteria for AEPs. According to Abedi, AEPs "(1) perceive themselves as challengers to the parties that makeup the political establishment; (2) they assert that a fundamental divide exists between the political establishment and the people (implying that all establishment parties, whether in government or in opposition, are essentially the same); (3) they challenge the status quo in terms of major policy issues and political system issues" (Abedi 2002: 556-557). The first criterion captures the self-perception of the role of AEPs; the second refers to how these parties define the nature of the political conflict; and the last criterion simply identifies 
the content of policies that these parties introduce and advocate (Abedi 2006: 18-20). Nevertheless, AEPs should not be mistaken for anti-system actors, since they seek not to dispose of democratic rule but only to point out the weaknesses of the rulers. Their critique is aimed at the political class, not at the democratic system per se. All the same, their criticism is broader than that deployed by parties taking a merely anti-incumbent opposition (Schedler 1996: 303).

At the same time, AEPs should not be conflated with populist parties, even though anti-establishment ideas are essential to the populist ideology alongside people-centrism and calls for restoration of popular sovereignty (Mudde 2004; Hawkins 2009; Rooduijn 2014). Yet, anti-establishment politics should be considered a broader category than populism, since anti-establishment politicians can propose other than merely populist solutions to the claimed crisis of political representation, including strong leadership, technocracy or a managerial approach to politics (see Engler et al. 2019; Hanley - Sikk 2016).

Nonetheless, research on the rise of populism as a "thin-centered ideology that considers society to be ultimately separated into two homogenous and antagonistic groups, 'the pure people' and the 'corrupt elite,' and which argues that politics should be an expression of the volonte general (general will of the people)" (Mudde 2004: 562) can serve as the basis for examining antiestablishment politics and anti-establishment attitudes. The same applies to research on populist attitudes. Recently, populist attitudes have been treated as a non-compensatory mutli-dimensional concept, i.e. a concept lying at the intersection of its three subdimensions, one of them being anti-establishment (commonly labelled as anti-elite) attitudes (see Wuttke et al. 2020). Although we fully acknowledge the whole to be greater than the sum of its parts, we believe that findings concerning the whole may at least to some extent apply to its parts. Consequently, we carefully make assumptions about anti-establishment attitudes from theory about populism and populist attitudes.

We conceptualize the people's anti-establishment attitudes as reflections of the core ideas of political parties' anti-establishment ideology. These core ideas translate into people's specific perceptions or attitudes, in the same way as the core ideas of any other thick or thin ideology, such as nationalism, socialism or conservatism. Based on the definition of AEPs and prior research on populism and populist attitudes, we understand anti-establishment attitudes to reflect a perception of politics that is based on emphasizing the constructed fundamental divide between the established political elite and the people. Opposition to established politicians is principled in the sense that politicians are seen as a homogeneous group that is corrupt, incompetent or otherwise incapable of representing the interests of the people. Yet, anti-establishment attitudes are not anti-democratic in the sense of opposing democratic institutions per se. 
To operationalize our dependent variable, anti-establishment attitudes, we have constructed a composite score by taking the arithmetic mean of four attitudinal items - anti1, anti2, anti3 and anti 4 - from the 2017 Czech National Election Study. Together with a few other items, these four items constitute the CSES populist attitudes scale, which has been proposed for the measurement of populist attitudes in the CSES Module 5.

Table 1: Items of the CSES scale capturing anti-establishment attitudes

\begin{tabular}{ll}
\hline Item & Wording \\
\hline anti1 & Most politicians do not care about the people. (R) \\
anti2 & Most politicians are trustworthy. \\
anti3 & Politicians are the main problem in the Czech Republic. (R) \\
anti4 & Most politicians care only about the interests of the rich and powerful. (R) \\
anti5 & How widespread do you think corruoption, such as bribe taking, is amongst politicians in the \\
& Czech Republic? (R) \\
\hline
\end{tabular}

Items used to create the composite score of anti-establishment attitudes are in bold. The first four items were measured on a 5 -point Likert scale $(1=$ strongly agree, $5=$ strongly disagree). The item anti5 was measured on a 4 -point Likert scale $(1=$ very widespread, $4=$ it hardly happens at all). For a more convenient interpretation of the results, scaling was reversed (R) for all items, except for the item anti2. Higher values thus indicate stronger anti-establishment attitudes.

Our selection of a set of items for operationalization of anti-establishment attitudes from the CSES scale was guided by both the conceptualization of antiestablishment attitudes and the CSES Module 5 documentation (Hobolt et al. 2016). Besides the four items which we use to construct the composite score of anti-establishment attitudes, the documentation suggests one additional item as a manifestation of these attitudes, specifically the item which asks respondents to evaluate the extent of corruption among politicians (see Table 1). However, we believe that this item captures perception of corruption rather than antiestablishment attitudes, and treat it accordingly. In contrast, the remaining four items truly capture the essence of anti-establishment attitudes, measuring different aspects of these attitudes. Item antil refers to the political elite's lack of interest in the people and their needs, as well as unwillingness to address these needs. Item anti4 further emphasizes the ignorance of the political elite to address people's needs by portraying the political elite as representatives only of the rich and powerful. Items anti2 and anti3 then capture the untrustworthiness and incompetence of the political elite.

Before calculating the composite score of anti-establishment attitudes, we performed confirmatory factor analysis (CFA) to test how well these items represent the latent construct of anti-establishment attitudes. Specifically, we ran CFA for both the four-item and the five-item models of anti-establishment attitudes. Overall, the results indicate that the four-item solution can be 
adopted. Nevertheless, differences in fit between the models are very small (see Table 2).

Table 2: CFA outputs for 4-item and 5-item model of anti-establishment attitudes

\begin{tabular}{llll}
\hline \multirow{2}{*}{ Item } & Wording & $\begin{array}{l}\text { Factor loadings } \\
\text { 5-item model }\end{array}$ & 4-item model \\
& & Est. (SE) & Est. (SE) \\
\hline anti1 & Most politicians do not care about the people. & $0.736(0.022)$ & $0.750(0.024)$ \\
anti2 & Most politicians are trustworthy. & $0.522(0.030)$ & $0.515(0.031)$ \\
anti3 & Politicians are the main problem in the Czech Republic. & $0.563(0.026)$ & $0.561(0.027)$ \\
anti4 & Most politicians care only about the interests of the rich & $0.732(0.022)$ & $0.723(0.026)$ \\
& and powerful. & & \\
anti5 & How widespread do you think corruoption, such as bribe & $0.502(0.026)$ & - \\
& taking, is amongst politicians in the Czech Republic? & & 6.584 \\
\hline & $\chi^{2}$ & 10.066 & 2 \\
& df & 5 & 0.037 \\
& p-value & 5 & 0.042 \\
& RMSEA & 0.073 & 0.009 \\
& Lower CI & 0.028 & 0.078 \\
& Upper CI & & 0.013 \\
& SRMR & 0.000 & 0.994 \\
& CFI & 0.050 & 0.982 \\
& AIC & 0.015 & 14350.234 \\
& & 0.995 & 0.727 \\
\hline
\end{tabular}

Maximum likelihood estimation with robust Huber-White standard errors and a scaled test statistic (MLR) was used as the estimation method. Standardized solutions are reported.

Table 2 about here

We prefer the model without the anti5 item as we believe that the wording of this item encourages respondents to focus on corruption rather than on politicians. The focus on corruption is partly caused by the placement of this item in the questionnaire - the anti5 item was answered by respondents much later in the survey. Consequently, we only used the antil to anti4 items to calculate the composite score of anti-establishment attitudes.

For each respondent, a composite score was created by taking the arithmetic mean of his or her scores on these four items, each measured on a five-point Likert scale $(1=$ strongly disagree to $5=$ strongly agree $)$. The composite score thus ranges from 1 to 5 , with higher values indicating stronger anti-establishment attitudes. 
Anti-establishment politics in the Czech Republic

Various surveys indicate that a deep divide between the people and the political elite has gradually emerged in the Czech Republic. Between the years 2005 and 2017, the overall satisfaction with the political situation in the Czech Republic was extremely low, fluctuating between 5\% and 23\%, while the level of dissatisfaction ranged from $32 \%$ in 2005 to $75 \%$ (CVVM 2019a). The increasing dissatisfaction with politics clearly mirrored declining levels of trust in both chambers of the parliament as well as the government (CVMM 2019b). Nevertheless, the presence of a significant divide between the people and the elite is best captured in the public's prevailing perception that most politicians do not care about what their constituents think (CVVM 2019b).

No wonder that the widespread negative perception of politics and politicians has translated into the recent electoral success of anti-establishment political parties. What is unique about the Czech case is the emergence of different types of AEPs, not limited to those with a radical ideological profile. The first successful AEP was Public Affairs (VV), which secured 10.9\% of the vote in the 2010 legislative election. This party clearly distanced itself from the political establishment by claiming to be "against everyone" and advocating "removal of all 'dinosaurs' from Czech politics". The party's distrust of established politicians was also well reflected in its calls for strengthening direct democracy, attempts to recall politicians to make them accountable, and its attempt to fight corruption, which was one of the main themes of its campaign (Havlík 2015). The ideological profile of the party was vague and often contradictory (Havlík - Hloušek 2014). Despite its strong antiestablishment appeal, the party joined the government coalition. However, the party faced frequent disputes and allegations of corruption, which ended in its break-up, and the subsequent erosion of the government. In the next general elections VV did not run (Kopeček et al. 2018: 72-73).

The resulting political crisis opened up opportunities for the emergence of other anti-establishment actors. One of the new players in the political arena was the Alliance of Dissatisfied Citizens (ANO) 2011. From the very beginning, ANO has positioned itself as a party with an unclear centrist ideological profile (Havlík 2019) but a strong anti-establishment appeal (Van Kessel 2015: 41). As the party leader, Andrej Babiš, stated: "The main problems of the Czech Republic are incompetent and unprofessional politicians" (Babiš 2013). After winning 18.7\% of votes in the 2013 Czech legislative election, ANO became an important component of the new government coalition (Havlík 2019). Following the recovery of the Czech economy, ANO even won the subsequent general election in 2017. 
Concurrently with the electoral success of ANO, another AEP managed to enter the Czech parliament - the Dawn of Direct Democracy led by Tomio Okamura. The party was founded in 2013 by an entrepreneur and politician named Tomio Okamura. After its initial centrist ideological profile with a strong anti-establishment appeal, Dawn (and later, Okamura's new Freedom and Direct Democracy Party) embraced a typical radical right profile, including outspoken nativism and Euroscepticism (van Kessel 2015: 42; Šárovec 2018). The party secured $6.9 \%$ of the vote in 2010 and almost doubled its vote share four years later.

Last but not least, the Czech Pirate Party entered parliament in 2017 with $10.8 \%$ of the vote. Besides its libertarian roots and emphasis on several liberal issues, the most distinguishing feature of the party was its anti-establishment appeal and rejection of the left-right divide in party competition. Its main election slogan, "Let Us Go After Them!" ("Pust'te nás na ně!" in Czech), as well as its election bus featuring a caricature depicting Czech politicians as prisoners, illustrate the party's stress on the alleged corruption of the established politicians. In their campaign, the Pirates emphasized transparency in politics, an anti-corruption agenda, and greater involvement of the general public in decision making.

To summarize, anti-establishment appeals have recently played a prominent role within the Czech party system. Unlike anti-establishment political parties in many Western European countries, the Czech parties have not concentrated exclusively at the extreme poles of the ideological spectrum, but also at the centre. Such AEPs present an ambiguous profile, focusing mainly on the corruption and incompetence of the established political elite as the crucial issue in Czech politics.

Theoretical expectations

To identify correlates of anti-establishment attitudes, we build on existing research on voting for AEPs and populist parties as well as the literature concerning the origins of populist attitudes, while considering context-specific explanations related to Czech politics. Specifically, we explore four groups of plausible explanations of anti-establishment attitudes: (1) socio-economic deprivation and economic voting, (2) sociocultural explanations (the nationalism vs. universalism divide), (3) political efficacy and protest voting, and (4) ideological proximity voting.

The first theoretical expectation we test is drawn from the literature on socio-economic deprivation and economic voting. Previous studies describe the connection between support for AEPs and people who are vulnerable in socioeconomic terms. The argument is closely tied to discussion about the effects of globalization, which is argued to have created a new structural conflict in 
contemporary societies. This conflict has its "winners", such as entrepreneurs and qualified employees in sectors open to international competition, and "losers". These are business owners and employees working in traditionally protected sectors, as well as unqualified employees and those who identify themselves with a national rather than cosmopolitan community.

In this new conflict, the political establishment is blamed for the precarious position of the people on the losing side (Kriesi et al. 2006, 2012; Hawkins et al. 2012). Elchardus and Spruyt et al. (2016) suggest that people with low levels of education could opt for populism as an expression of revolt against the political establishment. Lower educational status may make these people identify themselves more with "ordinary people", in opposition to the political elite. The positive effect of low education on populist beliefs has been shown in many studies (Anduiza - Rico 2016; Elchardus - Spruyt 2016; Hawkins et al. 2012; Oliver - Rahn 2016; Tsatsanis et al. 2018), yet the strength of the relationship varies considerably (c.f. Silva et al. 2017). Furthermore, Anduiza and Rico (2016) argue that what truly matters is not an individual's economic position, but rather "group-based judgments of economic conditions". If populism actually is the product of a "plurality of unsatisfied demands", all the more reason for the perception of grievances shared by a community identified as "the people", rather than individual economic hardship, to play a paramount role in explaining citizens' degreeof populist attitudes. Similarly, Elchardus and Spruyt (2016) find that both relative deprivation, i.e. the feeling of belonging to a social group that is deprived, and declinism, i.e. the perception that society is in decline and unable to face various challenges (economic, environmental, cultural etc.), has a stronger direct effect on populist attitudes than one's personal economic position (but see Tsatsanis et al. 2018 for contrary results).

Kreidl and Vlachová (1999) found out that US workers and employees with a vocational level of education, small entrepreneurs, and people with no religious affiliation tended to vote for the anti-establishment far-right Republicans during the 1990s. Support for Republican Party candidates was concentrated in areas of lower population density, higher unemployment and higher criminality. Nevertheless, the explanatory power of these socioeconomic deprivation or grievance theories seems to be lower in the Czech context (Maškarinec - Bláha 2014), although not negligible (Maškarinec 2019). Therefore, the first set of explanations for anti-establishment attitudes concerns individuals' socio-economic position as well their judgment of the country's economic conditions. To test this theoretical expectation, we formulate the following hypotheses:

H1a: People with lower education hold stronger anti-establishment attitudes. 
H1b: People with negative socio-tropic perceptions of the national economy hold stronger anti-establishment attitudes.

We also expect the losers of globalization to adopt anti-establishment attitudes in response to cultural competition and fears (nationalistic and protectionist approaches vs. universalist approach) provoked by globalization. Contemporary European societies are facing mass migration, loosening of national borders, and inflows of foreign cultural elements. While the winners of globalization benefit from these changes, the losers feel threatened by them in terms of security (fear of terrorism) or culture (multiculturalism vs. nationalism), thus preferring in response to control the national borders. The losers may blame the current political elite for bringing about such a situation or failing to remedy their cultural fears. The feelings of threat are translated into negative attitudes towards migrants, the European Union and economic liberalism and, therefore, should be relevant to the holding of anti-establishment attitudes (Mudde 2007; Ivarsflaten 2008; Polk - Rovny 2017). Considering the strong xenophobic (SPD) and Eurosceptic (SPD, and to some extent ANO) nature of Czech AEPs (Kaniok - Havlík 2016), our expectation that these factors shape anti-establishment attitudes in the Czech context are expressed in the following hypotheses:

H2a: People with negative stances towards migration hold stronger antiestablishment attitudes.

H2b: People with Eurosceptic stances hold stronger anti-establishment attitudes.

H2c: People with negative stances towards economic liberalism hold stronger anti-establishment attitudes.

Moreover, anti-establishment attitudes could be a response to the feeling that the political system is dysfunctional. The very foundation of a democratic polity is built on the responsiveness and accountability of political elites and the people's expectations that the elites will behave in their interest. As Canovan (1999) points out, "[i]f it becomes clear that those involved see in democracy as nothing but horsetrading, they, and eventually the system itself, are liable to lose their legitimacy. When too great a gap opens up between haloed democracy and the grubby business of politics, populists tend to move on to the vacant territory, promising in place of the dirty world of party manoeuvring the shining ideal of democracy renewed" (p. 11).

Spruyt et al. (2016) argue that populism is an attitude held by people "who feel their voice does not matter in politics". It is the lack of external political efficacy, a belief that the actions of individuals cannot influence or change public affairs, that may play a key role in developing anti-establishment attitudes. However, we have conceptualized AEPs as semi-loyal and pro- 
democratic, situated between the anti-incumbent opposition and the antidemocratic opposition. If AEP actors are indeed semi-loyal, we should see no effect of anti-democratic views on anti-elitism.

As already mentioned above, one of the core issues stressed by AEPs is corruption. In recent years, the Czech political system has provided opportunities for the growth of anti-establishment attitudes. Corruption has been at the forefront of the anti-establishment discourse of the newly emerged political parties (Havlík 2015). Very few Czechs are satisfied with the state of public corruption. Between 2003 and 2017, this figure ranged from 2\% to 4\% of the population, whereas the level of dissatisfaction ranged from $67 \%$ to $92 \%$ (CVVM 2019a). Therefore, we assume that the perception of corruption will play a role in explaining anti-establishment attitudes. Hence, we expect that:

H3a: People with feelings of low political efficacy hold stronger antiestablishment attitudes.

$\mathrm{H} 3 \mathrm{~b}$ : There will be no link between anti-establishment attitudes and antidemocratic attitudes.

H3c: People with a negative perception of corruption hold stronger antiestablishment attitudes.

Finally, there is a growing body of evidence that, on the party level, voting for populist parties and having populist attitudes is strongly associated with left-right radicalism (Rooduijn - Akkerman 2017), and there is also some evidence that such radicalism may matter more for populist attitudes (Hawkins et al. 2012; Oliver - Rahn 2016). However, anti-establishment attitudes in the Czech Republic may be linked rather to ideological centrism. The most successful anti-establishment party in the Czech Republic, ANO, has presented a rather ideologically ambiguous, centrist profile. In its campaigns, ANO framed the elites as corrupt and urged voters to adopt its anti-establishment views while eschewing ideological radicalism. Similarly, the Public Affairs Party, and originally Dawn of Direct Democracy as well, combined a vaguely centrist ideological profile with fierce criticism of the political elites, stressing the incompetence and corruption scandals of the incumbents (Havlík - Hloušek 2014, Havlík 2015). Okamura's party later switched, however, from undefined ideological centrism to political radicalism. Nevertheless, we believe that the specific context of the Czech party system and the prevalence of centrist antiestablishment parties influence origins of anti-establishment attitudes among the general public. Thus, we argue that:

H4: People with centrist self-positioning hold stronger anti-establishment attitudes.

Sociológia 53, 2021, No. 3 
Data and methods

To test our hypotheses we used data from the 2017 Czech National Election Study. The study maps voting behaviour and political attitudes and was conducted by the Public Opinion Research Centre (CVVM) on a representative sample of the Czech electorate $(\mathrm{N}=1559)$, shortly after the 2017 Czech legislative election. The data were collected through personal interviews with respondents. Our final sample is lower $(\mathrm{N}=919)$ as we excluded respondents with missing values for any of the variables of interest. However, this adjustment does not considerably distort the sample's representativeness.

We employed OLS regression analysis to test three groups of explanations of anti-establishment attitudes. Model 1 embraces only socioeconomic determinants of anti-establishment attitudes, namely the level of educational attainment (elementary education; higher education - vocational certificate; higher education - graduation exam; tertiary or university education) and sociotropic economic perceptions (the Czech economy improved, stayed the same, or worsened in the last 12 months).

Model 2 newly incorporates explanations connected to cultural fears, namely Euroscepticism, economic liberalism, and anti-immigration stances. Each of these variables was measured using a pair of opposing statements, defining the endpoints of a 10-point response scale. Respondents could indicate which of the opposing statements they most identified with. Anti-immigration stances are captured in respondents' preferences for adopting more restrictive laws concerning migrants and granting asylum (strong, moderate, or weak antiimmigration attitudes). Euroscepticism is operationalized by asking whether European integration has gone too far (strong, moderate, or weak Euroscepticism). The perceived necessity to limit the inflow of foreign capital, since it reduces the economic independence of the country, is then used as an indicator of attitudes towards economic liberalism (strong, moderate or weak antiliberalism).

The last group of explanations, which are newly found in Model 3, approach anti-establishment attitudes as a function of political disenchantment and ideological non-radicalism. Specifically, the effects of four variables are examined, the first one being political efficacy. This "feeling that individual political action does have, or can have, an impact upon the political process" (Campbell et al. 1954: 187) is captured by asking about perceptions of the impact of voting, i.e. whether voting for a particular candidate or party can change a lot of things (high political efficacy) or does not change anything (low political efficacy). The next variable is the perceived salience of corruption, i.e. the perception of how common corruption, such as taking bribes, is among Czech politicians (very common/ common/ not so common). The third variable captures anti-democratic views. These refer to the belief that under some 
circumstances an authoritarian regime or dictatorship may be better than democracy. The last variable is ideological non-radicalism. This variable is operationalized using the left-right ideological non-placement on an 11-point scale. Those placing themselves around the middle (3 to 7) are considered to hold non-radical political views, while those placing themselves close to either pole of the scale are considered to hold radical political views.

Results

Before examining individual explanations for anti-establishment attitudes, we briefly discuss the general level of anti-establishment attitudes among the Czech public. The mean level of anti-establishment attitudes in our sample $(1=$ weak anti-establishment attitudes, $5=$ strong anti-establishment attitudes) is rather high. When we look at the percentage of responses to items of the antiestablishment scale, we see that most people (rather) agree that politicians do not care about the people, and that believe that politicians cannot be trusted. The majority of respondents also (rather) believe that most politicians care only about the interests of the rich and powerful, and over $40 \%$ perceive politicians as the main problem for the country. All-in-all these findings indicate that antiestablishment attitudes seem to be quite prevalent in the Czech public.

These results are hardly surprising, given the strong presence of antiestablishment politics within the Czech party system as well as the prevalence of related attitudes among the general public. Similarly to evidence from numerous case studies, these results are in line with the general trend of relatively high levels of anti-establishment attitudes all over Europe (c.f. Anduiza - Rico 2016).

Table 3: Descriptive characteristics of anti-establishment attitudes scale items among the Czech public

\begin{tabular}{|c|c|c|c|c|c|}
\hline & $\begin{array}{l}\text { (Strongly) } \\
\text { agree }\end{array}$ & $\begin{array}{l}\text { (Strongly) } \\
\text { disagree }\end{array}$ & Neither & Mean & SD \\
\hline anti1: Most politicians do not care about people. & $64.8 \%$ & $14.7 \%$ & $20.5 \%$ & 3.72 & 1.02 \\
\hline anti2: Most politicians are trustworthy. & $10.0 \%$ & $63.8 \%$ & $26.2 \%$ & 3.77 & 0.96 \\
\hline $\begin{array}{l}\text { anti3: Politicians are the main problem in the } \\
\text { Czech Republic. }\end{array}$ & $44.6 \%$ & $30.2 \%$ & $25.2 \%$ & 3.30 & 1.14 \\
\hline $\begin{array}{l}\text { Most politicians care only about the interests of } \\
\text { the rich and powerful. }\end{array}$ & $57.1 \%$ & $17.9 \%$ & $25.0 \%$ & 3.59 & 1.07 \\
\hline Anti-establishment attitudes (1-5) & & & & 3.59 & 0.78 \\
\hline
\end{tabular}

The results of our regression analyses are summarized in Figure 2 and Table 4. It is rather apparent that in the Czech context anti-establishment attitudes are not rooted in socioeconomic explanations. The regression model with only socioeconomic predictors (Model 1) explains very little variation in anti- 
establishment attitudes (Adjusted $\mathrm{R}^{2}=0.027$ ). Furthermore, neither education nor sociotropic perception of the economy seem to have a substantial effect on anti-establishment attitudes in our regression models.

Figure 2: Coefficient estimates of Regression Models

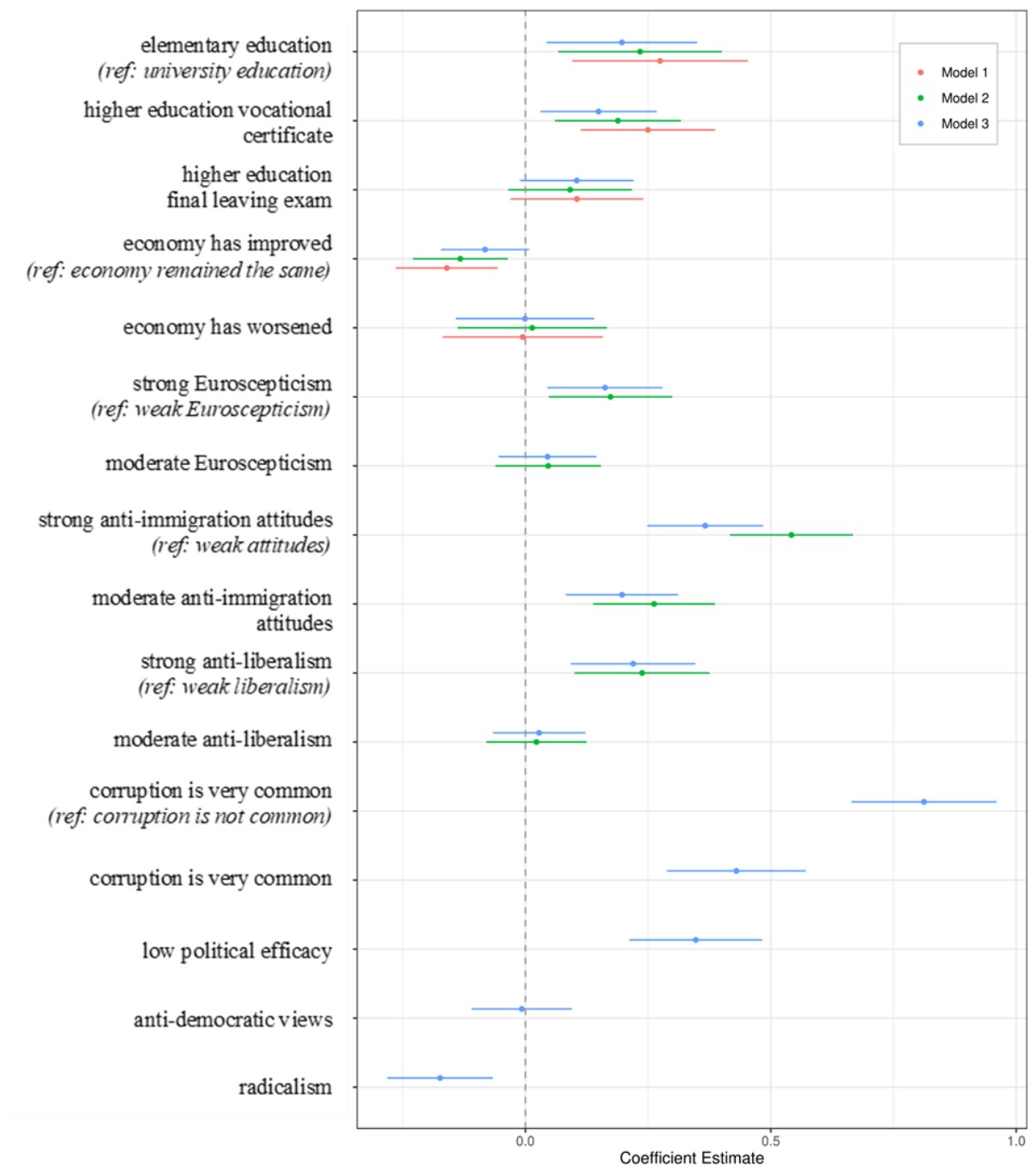

Dots correspond to unstandardized estimates of regression coefficients. Lines depict corresponding $95 \%$ confidence intervals. The intersecting dotted line marks zero effect on dependent variable (anti-estbalishment attitudes). Values on the left indicate negative effect, while values on the right indicate positive effect. 
Table 4: Regression results

\begin{tabular}{|c|c|c|c|}
\hline & \multicolumn{3}{|c|}{ Dependent variable: } \\
\hline & \multicolumn{3}{|c|}{ Anti-establishment atttitudes } \\
\hline & $(1)$ & (2) & (3) \\
\hline \multirow{3}{*}{ elementary education } & 0.117 & 0.100 & 0.084 \\
\hline & $(0.091)$ & $(0.085)$ & $(0.078)$ \\
\hline & $\mathrm{p}=0.199$ & $\mathrm{p}=0.240$ & $\mathrm{p}=0.282$ \\
\hline \multirow{3}{*}{$\begin{array}{l}\text { higher education - } \\
\text { vocational certificate }\end{array}$} & 0.158 & 0.119 & 0.094 \\
\hline & $(0.070)$ & $(0.065)$ & $(0.060)$ \\
\hline & $\mathrm{p}=0.024$ & $\mathrm{p}=0.069$ & $\mathrm{p}=0.119$ \\
\hline \multirow{3}{*}{$\begin{array}{l}\text { higher education - final } \\
\text { leaving exam }\end{array}$} & 0.067 & 0.058 & 0.067 \\
\hline & $(0.069)$ & $(0.064)$ & $(0.059)$ \\
\hline & $\mathrm{p}=0.332$ & $\mathrm{p}=0.365$ & $\mathrm{p}=0.258$ \\
\hline \multirow{3}{*}{ economy has improved } & -0.107 & -0.088 & -0.055 \\
\hline & $(0.053)$ & $(0.049)$ & $(0.046)$ \\
\hline & $\mathrm{p}=0.044$ & $\mathrm{p}=0.073$ & $\mathrm{p}=0.230$ \\
\hline \multirow{3}{*}{ economy has worsened } & -0.002 & 0.006 & -0.0004 \\
\hline & $(0.083)$ & $(0.078)$ & $(0.072)$ \\
\hline & $\mathrm{p}=0.978$ & $\mathrm{p}=0.940$ & $\mathrm{p}=0.997$ \\
\hline \multirow{3}{*}{ strong euroscepticism } & & 0.105 & 0.098 \\
\hline & & $(0.064)$ & $(0.060)$ \\
\hline & & $\mathrm{p}=0.103$ & $\mathrm{p}=0.101$ \\
\hline \multirow{3}{*}{ moderate euroscepticism } & & 0.030 & 0.029 \\
\hline & & $(0.055)$ & $(0.051)$ \\
\hline & & $\mathrm{p}=0.586$ & $\mathrm{p}=0.567$ \\
\hline \multirow{3}{*}{$\begin{array}{l}\text { strong anti-immigration } \\
\text { atttitudes }\end{array}$} & & 0.359 & 0.243 \\
\hline & & $(0.064)$ & $(0.060)$ \\
\hline & & $\mathrm{p}=0.00000$ & $\mathrm{p}=0.0001$ \\
\hline \multirow{3}{*}{$\begin{array}{l}\text { moderate anti-immigration } \\
\text { attitudes }\end{array}$} & & 0.167 & 0.125 \\
\hline & & $(0.063)$ & $(0.058)$ \\
\hline & & $\mathrm{p}=0.009$ & $\mathrm{p}=0.032$ \\
\hline \multirow{3}{*}{ strong anti-liberalism } & & 0.116 & 0.107 \\
\hline & & $(0.070)$ & $(0.065)$ \\
\hline & & $\mathrm{p}=0.099$ & $\mathrm{p}=0.097$ \\
\hline \multirow{3}{*}{ moderate anti-liberalism } & & 0.014 & 0.017 \\
\hline & & $(0.052)$ & $(0.048)$ \\
\hline & & $\mathrm{p}=0.792$ & $\mathrm{p}=0.721$ \\
\hline
\end{tabular}

Sociológia 53, 2021, No. 3 


\begin{tabular}{|c|c|c|c|}
\hline & \multicolumn{3}{|c|}{ Dependent variable: } \\
\hline & \multicolumn{3}{|c|}{ Anti-establishment attitudes } \\
\hline & (1) & (2) & (3) \\
\hline \multirow{3}{*}{ corruption is very common } & & & 0.526 \\
\hline & & & $(0.075)$ \\
\hline & & & $\mathrm{p}=0.000$ \\
\hline \multirow{3}{*}{ corruption is common } & & & 0.287 \\
\hline & & & $(0.072)$ \\
\hline & & & $\mathrm{p}=0.0001$ \\
\hline \multirow{3}{*}{ low political efficacy } & & & 0.145 \\
\hline & & & $(0.069)$ \\
\hline & & & $\mathrm{p}=0.036$ \\
\hline \multirow{3}{*}{ anti-democratic views } & & & -0.004 \\
\hline & & & $(0.052)$ \\
\hline & & & $\mathrm{p}=0.938$ \\
\hline \multirow{3}{*}{ radicalism } & & & -0.090 \\
\hline & & & $(0.055)$ \\
\hline & & & $\mathrm{p}=0.102$ \\
\hline \multirow{3}{*}{ Constant } & 0.000 & 0.000 & 0.000 \\
\hline & $(0.065)$ & $(0.078)$ & $(0.093)$ \\
\hline & $\mathrm{p}=1.000$ & $\mathrm{p}=1.000$ & $\mathrm{p}=1.000$ \\
\hline Observations & 919 & 919 & 919 \\
\hline $\mathrm{R}^{2}$ & 0.033 & 0.173 & 0.308 \\
\hline Adjusted $\mathrm{R}^{2}$ & 0.027 & 0.163 & 0.295 \\
\hline F Statistic & $\begin{array}{c}6.151^{* * *} \\
(\mathrm{df}=5 ; 913)\end{array}$ & $\begin{array}{c}17.196^{* * *} \\
(\mathrm{df}=11 ; 907)\end{array}$ & $\begin{array}{c}25.038^{* * *} \\
(\mathrm{df}=16 ; 902)\end{array}$ \\
\hline
\end{tabular}

Note: ${ }^{*} \mathrm{p}<0.1 ;{ }^{* *} \mathrm{p}<0.05 ;{ }^{* * *} \mathrm{p}<0.01$

For each explanatory variable, its standardized beta coefficient, associated standard error (in the parentheses) and p-value are reporeted. We have also run all three models with age and gender as controls. Adding these variables to the model however did not help to explain differences in anti-estbalishment attitudes, nor had it a considerable impact on the results.

The association between education and anti-establishment attitudes is positive. More specifically, people who have completed elementary education as well as people who have completed high school education have stronger anti-establishment attitudes compared to those who hold a university degree. The direction of this effect is in line with our theoretical reasoning, as well as with recent findings in Poland, where lower level of education was found to contribute to stronger populist attitudes (Stanley 2019). However, due to the rather weak size of the effect (and associated standard error) we do not have enough evidence to support our hypothesis that lower-educated people tend to hold stronger anti-establishment attitudes (H1a). 
The effect of sociotropic perceptions of the economy on anti-establishment attitudes is even weaker. People who believe the Czech economy has improved do not have much weaker anti-establishment attitudes compared to those who believe the economy did not change. At the same time, people who perceive that the Czech economy has gotten worse do not have much stronger antiestablishment attitudes compared to those who believe it remained the same. We therefore do not find enough evidence to support our hypothesis that people with negative socio-tropic perceptions of the national economy tend to hold stronger anti-establishment attitudes (H1b). Overall, the observed weak association between socioeconomic explanations and anti-establishment attitudes thus supports earlier findings suggesting lower explanatory power of socioeconomic deprivation for political views in the Czech context (Maškarinec - Bláha 2014).

On the contrary, explanations connected to cultural fears seem to be more meaningful predictors of anti-establishment attitudes. Adding these variables into the regression model (Model 2) results in much better explanation of differences in anti-establishment attitudes (Adjusted $\mathrm{R}^{2}=0.163$ ). However, the ability of individual variables to explain anti-establishment attitudes varies considerably. Neither negative stances on economic liberalism, nor Euroscepticism seem to be meaningful predictors of anti-establishment attitudes in the Czech context. Both of these predictors are positively associated with antiestablishment attitudes, which fully corresponds to our expectations about the direction of their effects, but due to the low size of the effect of both variables (and associated standard errors being relatively high) we do not find support for the respective hypotheses $(\mathrm{H} 2 \mathrm{~b}$ and $\mathrm{H} 2 \mathrm{c})$.

Rather than being explained by anti-liberalism and Euroscepticism, antiestablishment attitudes are rooted in anti-immigration stances. Consistent with the respective hypothesis $(\mathrm{H} 2 \mathrm{a})$, our findings indicate that people with antiimmigration stances have stronger anti-establishment attitudes relative to those holding weaker anti-immigration attitudes. This pattern is prominent especially for individuals with strong anti-immigration attitudes.

Similar patterns are observed in Model 3. In the Czech context, stances on migration, therefore, are a meaningful contributor to negative perceptions and evaluations of the political establishment. These results thus indirectly correspond to earlier findings from Poland, where cultural explanations, and migration in particular, were found to have a considerable impact on populist attitudes (see Stanley 2019).

The last group of explanations which we examine are connected to political disenchantment and ideological radicalism. Overall, adding these explanations into the regression model (Model 3) results in a much better explanation of differences in anti-establishment attitudes (Adjusted $\mathrm{R}^{2}=0.295$ ). 
Most of the results which we observe are in line with our hypotheses. The only exception is the expected positive association between centrist ideological self-placement and anti-establishment attitudes (H4). The direction of the effect corresponds to our expectations, i.e. people who place themselves at either end of the left-right ideological scale tend to have weaker anti-establishment attitudes compared to those who place themselves at and around the middle. However, due to the rather low size of the effect (and associated standard error) we do not have enough evidence to support the respective hypothesis.

However, we do find support for our hypothesis suggesting no association between anti-establishment attitudes and anti-democratic attitudes (H3b). The effect of anti-democratic stances on anti-establishment attitudes is negligible. This result is consistent with recent findings indicating that those who are hostile to the political establishment do not necessarily hold anti-democratic views (Kaltwasser - van Hauwaert 2020).

Nonetheless, political disenchantment does play a role in shaping antiestablishment attitudes in the Czech context. People who believe that voting does not change anything have stronger anti-establishment attitudes compared to those who believe that voting can change many things. This moderate positive association between political efficacy and anti-establishment attitudes is thus in line with our hypothesis (H3a). In light of the existing research on centrist anti-establishment political parties in Central and Eastern Europe (Hanley - Sikk 2016; Engler 2020) and populist attitudes (Kaltwasser - van Hauwaert 2020), our findings are hardly surprising.

Perception of corruption is an even more substantial predictor of antiestablishment attitudes than feelings of low political efficacy. People who believe that corruption is (very) common among politicians have stronger antiestablishment attitudes. This rather strong positive relationship is in line with our hypothesis $(\mathrm{H} 3 \mathrm{c})$. In Czechia specifically, this may result from the recent series of corruption scandals combined with a strong emphasis of antiestablishment and populist parties on corruption in the political establishment.

Discussion and conclusion

Using data from the 2017 Czech National Election Study, this study finds that anti-establishment attitudes in the Czech public are rooted in anti-immigration stances, feelings of low political efficacy and especially the perception of widespread corruption among politicians. The key contribution of our study is to demonstrate how explanations of populist attitudes can be applied to examine the causes of anti-establishment attitudes. Yet only some of these explanations seem to resonate in the Czech context.

The results show that anti-establishment attitudes arise partly in response to globalization and associated rising cultural competition. Cultural fears reflected 
in strong anti-immigration sentiments seem to be an important seed of antiestablishment attitudes. In this sense, the findings suggest that it is the perception of threat that truly matters rather than actual (negative) experiences with migration.

Contrarily, an individual's socio-economic vulnerability does not seem to be connected to anti-establishment attitudes in the Czech context. Similarly, people's radicalism does not seem to shape their anti-establishment views. What matters is political disenchantment, particularly feelings of low political efficacy and the perceived salience of corruption, both of which are positively associated with anti-establishment attitudes.

The reason why some of the proposed explanations for anti-establishment attitudes do or do not work may be threefold. First, factors shaping antiestablishment attitudes may differ from factors shaping populist attitudes. We believe that future research should explore this option. Second, our findings might be bound up with the specifics of the Czech context. Future research should examine the roots of anti-establishment attitudes in multiple countries. It would be particularly interesting to see whether anti-establishment attitudes in different contexts share some of our proposed explanations. Third, most of our proposed explanations for anti-establishment attitudes were operationalized with a single item. We would like to encourage using longer item batteries for exploring the proposed effects in future studies. We believe it would be particularly interesting to explore whether both the economic and the cultural dimensions of anti-immigration attitudes shape people's anti-establishment attitudes.

Despite these limitations, we believe that our study offers a valuable insight into the roots of anti-establishment attitudes among the Czech public and is an important contribution to the existing research on populism and antiestablishment politics. That being said, it is necessary to examine further plausible causes of anti-establishment attitudes, such as the theory of declinism (Elchardus - Spruyt 2016) or the theory of relative economic deprivation (Anduiza - Rico 2016). We believe that it would also be very enriching to examine whether anti-establishment attitudes have their roots in personality traits, especially the anger trait. Overall, future research should focus on further exploration of the roots of anti-establishment attitudes, focusing on comparing the explanatory value of different models while considering the influence of the national context, including the effects of framing and cues provided by political actors, thus accounting for the variety of anti-establishment political actors. Finally, anti-establishment attitudes should be used as a predictor of support for anti-establishment parties or electoral turnout. 
Ondrej Škvarenina is a master student at Department of Political Science, Faculty of Social Studies, Masaryk university. He worked on this article at Masaryk University with the support of the Specific University Research Grant provided by the Ministry of Education, Youth and Sports of the Czech Republic (Aktuálni problémy politologického výzkumu VII. (MUNI/A/1324/2020).

Vlastimil Havlik is associate professor at Department of Political Science, Faculty of Social Studies, Masaryk university. He worked on this article in the framework of the grant project Radicalization of Politics in Central Europe in Times of Crises (GA1709296S) sponsored by the Grant Agency of the Czech Republic.

Veronika Dostálová is a doctoral student at Department of Political Science, Faculty of Social Studies, Masaryk university. worked on this article at Masaryk University with the support of the Specific University Research Grant provided by the Ministry of Education, Youth and Sports of the Czech Republic (Aktuálni problémy politologického výzkuтu VII. (MUNI/A/1324/2020).

\section{REFERENCES}

ABEDI, A., 2002: Challenges to Established Parties: The Effects of Party System Features on the Electoral Fortunes of Anti-Political-Eestablishment Parties. European Journal of Political Research 41(4): 551-583. https://doi.org/10.1111/1475-6765.t01-1-00022

ANDUIZA, E. - RICO, G., 2016: Economic Correlates of Populist Attitudes: An Analysis of Nine European Countries in the Aftermath of the Great Recession. Acta Politica 54(3): 371397. https://doi.org/10.1057/s41269-017-0068-7

BABIŠ, A., 2013: Dotace z EU? Víc nás trápí neschopnost politiků". Available at: http://andrejbabis.blog.idnes.cz/blog.aspx?c=336340

CAMPBELL, A. - GURIN, G. - MILLER, W. E., 1954: The voter decides. Evanston, Illinois: Row, Peterson

CANOVAN, M., 1999: Trust the People! Populism and the Two Faces of Democracy. Political Studies 47(1): 2-16. https://doi.org/10.1111/1467-9248.00184

CVVM, 2019a: Spokojenost se stavem vybraných oblastí veřejného života - únor 2019. Available at: https://cvvm.soc.cas.cz/media/com_form2content/documents/ c2/a488 3/f9/ps190319.pdf

CVVM, 2019b: Zájem politiků o názory občanů a možnosti občanů ovlivnit veřejnou sféru únor 2019. Available at: https://cvvm.soc.cas.cz/media/com_form2content/ documents/c2/a4885/f9/pd190320.pdf

ELCHARDUS, M. - SPRUYT, B., 2016: Populism, Persistent Republicanism and Declinism: An Empirical Analysis of Populism as a thin Ideology. Government and Opposition 51(1): 111-133. https://doi.org/10.1017/gov.2014.27

ENGLER, S., 2020: Centrist Anti-Establishment Parties and their Protest Voters: More than a Superficial Romance? European Political Science Review 12(3): 307-325. https://doi.org/10.1017/S1755773920000132 
ENGLER, S. - PYTLAS, B. - DEEGAN-KRAUSE, K., 2019: Assessing the Diversity of AntiEstablishment and Populist Politics in Central and Eastern Europe. West European Politics 42(6): 1310-1366. https://doi.org/10.1080/01402382.2019.1596696

EUROPEAN COMMISSION, 2018: Public Opinion in the European Union: Annex. Available at: http://ec.europa.eu/commfrontoffice/publicopinion/index.cfm/survey/ getsurveydetail/instruments/standard/surveyky/2215

HANLEY, S. - SIKK, A., 2016: Economy, Corruption or Floating Voters? Explaining the Breakthroughs of Anti-Establishment Reform Parties in Eastern Europe. Party Politics 22(4): 522-533. https://doi.org/10.1177/1354068814550438

HAVELKA, M., 1998. "Nepolitická politika": kontexty a traduce. ('Non-Political Polities': Contexts and Traditions.) Sociologický časopis/Czech Sociological Review 34(4): 455-466.

HAVLÍK, V., 2015: The Economic Crisis in the Shadow of Political Crisis: The Rise of Party Populism in the Czech Republic. In: Kriesi, H. - Pappas, T. (eds.): European Populism in the Shadow of the Great Recession. Colchester: ECPR Press, p. 199-216.

HAVLÍK, V., 2019: Technocratic Populism and Political Illiberalism in Central Europe. Problems of PostCommunism 6, no. 6, p. 369-384 https://doi.org/10.1080/10758216.2019.1580590

HAVLIK, V. - HLOUŠEK, V., 2014: Dr Jekyll and Mr Hyde: The Story of the Ppopulist Public Affairs Party in the Czech Republic. Perspectives on European Politics and Society 15(4): 552-570. https://doi.org/10.1080/15705854.2014.945254

HAWKINS, K. A., 2009: Is Chávez Populist? Measuring Populist Discourse in Comparative Perspective. Comparative Political Studies 42(8): 1040-1067. https://doi.org/10.1177/0010414009331721

HAWKINS, K. A. - RIDING, S. - MUDDE, C., 2012: Measuring Populist Attitudes. Available at: https://works.bepress.com/cas_mudde/72/

HOBOLT, S. - ANDUIZA, E. - CARKOGLU, A. - LUTZ, G. - SAUGER, N., 2016: Democracy Divided? People, Politicians and the Politics of Populism. CSES Planning Committee Module 5. Available from: http://www.cses.org/plancom/ module5/CSES5_ContentSubcommittee_FinalReport.pdf

INGLEHART, R. F. - NORRIS, P., 2016: Trump, Brexit, and the Rise of Populism: Economic have-nots and Cultural Backlash. HKS Working Paper No. RWP16-026. Available at: https://papers.ssrn.com/sol3/papers.cfm?abstract_id=2818659. https://doi.org/10.2139/ssrn.2818659

IVARSFLATEN, E., 2008: What Unites Right-Wing Populists in Western Europe? Re-examining Grievance Mobilization Models in Seven Successful Cases. Comparative Political Studies 41(1): 3-23. https://doi.org/10.1177/0010414006294168

KALTWASSER, C. R. - VAN HAUWAERT, S. M., 2020: The Populist Citizen: Empirical Evidence from Europe and Latin America. European Political Science Review 12(1): 1-18. https://doi.org/10.1017/S1755773919000262

KANIOK, P. - HAVLÍK, V., 2016: Populism and Euroscepticism in the Czech Republic: Meeting Friends or Passing by? Romanian Journal of European Affairs 16(2): 20-35.

KREIDL, M. - VLACHOVÁ, K., 1999: Sociální zázemí extrémní pravice v ČR: Voliči SPR-RSČ v letech 1996 - 1998. Sociologický časopis/Czech Sociological Review 35(3): 335-354. https://doi.org/10.13060/00380288.1999.35.3.07

KRIESI, H. - GRANDE, E. - LACHAT, R. - DOLEZAL, M. - BORNSCHIER, S. - FREY, T., 2006: Globalization and the Transformation of the National Political Space: Six European Countries Compared. European Journal of Political Research 45(6): 921-956. https://doi.org/10.1111/j.14756765.2006.00644.x

KRIESI, H. - GRANDE, E. - DOLEZAL, M. - HELBLING, M. - HÖGLINGER, D. - HUTTER, S. WÜEST, B., 2012: Political Conflict in Western Europe. Cambrigde: Cambridge University Press. https://doi.org/10.1017/CBO9781139169219

MAIR, P., 2013: Ruling the Void: The Hollowing of Western Democracy. London: Verso Trade.

MAŠKARINEC, P., 2019: The Rise of New Populist Political Parties in Czech Parliamentary Elections between 2010 and 2017: The Geography of Party Replacement. Eurasian Geography and Economics 60(5): 511-547. https://doi.org/10.1080/15387216.2019.1691928

MAŠKARINEC, P. - BLÁHA, P., 2014: For whom the Bell Tolls: Grievance Theory and the Rise of New Political Parties in the 2010 and 2013 Czech Parliamentary Elections. Sociológia 46(6): 706731.

Sociológia 53, 2021, No. 3 
MUDDE, C., 2004: The Populist Zeitgeist. Government and Opposition 39(4): 541-563. https://doi.org/10.1111/j.1477-7053.2004.00135.x

MUDDE, C., 2007: Populist Radical Right Parties in Europe. Cambridge: Cambridge University Press. https://doi.org/10.1017/CBO9780511492037

OLIVER, J. E. - RAHN, W. M., 2016: Rise of the Trumpenvolk: Populism in the 2016 Election. The ANNALS of the American Academy of Political and Social Science 667(1): 189-206. https://doi.org/10.1177/0002716216662639

POLK, J. - ROVNY, J., 2017: Anti-Elite/Establishment Rhetoric and Party Positioning on European Integration. Chinese Political Science Review 2(3): 356-371. https://doi.org/10.1007/s41111-0170068-9

ROODUIJN, M., 2014: The Nucleus of Populism: In Search of the Lowest Common Denominator. Government and Opposition 49(4): 573-599. https://doi.org/10.1017/gov.2013.30

ROODUIJN, M. - AKKERMAN, T., 2017: Flank Attacks: Populism and Left-Right Radicalism in Western Europe. Party Politics 23(3): 193-204. https://doi.org/10.1177/1354068815596514

SCHEDLER, A., 1996: Anti-Political-Establishment Parties. Party Politics 2(3(: 291-312. https://doi.org/10.1177/1354068896002003001

SILVA, B. - VEGETTI, F. - LITTVAY, L., 2017: The Elite is up to Something: Exploring the Relation between Populism and Belief in Conspiracy Theories. Swiss Political Science Review 23(4): 423-443. https://doi.org/10.1111/spsr.12270

SPRUYT, B. - KEPPENS, G. - VAN DROOGENBROECK, F., 2016: Who Supports Populism and what Attracts People to it? Political Research Quarterly 69(2): 335-346. https://doi.org/10.1177/1065912916639138

STANLEY, B., 2019: A New Populist Divide? Correspondences of Supply and Demand in the 2015 Polish Pparliamentary Elections. East European Politics and Societies 33(1): 17-43. https://doi.org/10.1177/0888325418783056

ŠÁROVEC, D., 2018: Nástup nových politických stran v ČR od roku 2013: hnutí ANO 2011 a Úsvit přímé demokracie pohledem konceptu novosti. Sociológia-Slovak Sociological Review, 50(1): 78113.

TSATSANIS, E. - ANDREADIS, I. - TEPEROGLOU, E., 2018: Populism from Below: SocioEconomic and Ideological Correlates of Mass Attitudes in Greece. South European Society and Politics 23(4): 429-450. https://doi.org/10.1080/13608746.2018.1510635

VAN KESSEL, S., 2015: Populist Parties in Europe: Agents of Discontent? Basingstoke: Palgrave Macmillan. https://doi.org/10.1057/9781137414113

WUTTKE, A. - SCHIMPF, C. - SCHOEN, H., 2020: When the whole is Greater than the Sum of its Parts: On the Conceptualization and Measurement of Populist Attitudes and other Multidimensional Constructs. American Political Science Review 114(2): 356-374. https://doi.org/10.1017/S0003055419000807 